DOI: 10.17951/lrp.2018.37.4.203-215

\author{
RenATA BEDNARZ-GRZYBEK \\ Uniwersytet Marii Curie-Skłodowskiej w Lublinie \\ https://orcid.org/0000-0002-5033-9163 \\ IZABELA KRASIŃSKA \\ Uniwersytet Jana Kochanowskiego w Kielcach \\ https://orcid.org/0000-0002-5897-9333
}

\title{
POPULARYZACJA CZYTELNICTWA NA ŁAMACH POZNAŃSKIEGO PERIODYKU „RUCH CHRZEŚCIJAŃSKO-SPOŁECZNY” (1902-1910)
}

\begin{abstract}
Streszczenie: W wyniku uprzemysłowienia, jakie dokonało w XIX wieku, doszło do wzrostu liczebności klasy robotniczej, a zniesienie pańszczyzny (uwłaszczenie chłopów) spowodowało polepszenie bytu włościan. Zaczęły też ukazywać się książki i prasa adresowane do tych części społeczeństwa. Jednym z takich periodyków był „Ruch Chrześcijańsko-Społeczny” (1902-1910). Jego twórcy zachęcali do tworzenia katolickich robotniczych zrzeszeń zawodowych, krytykowali szerzący się ruch socjalistyczny, podkreślając jego antyreligijność, starali się odsunąć od wpływu na polskie życie gospodarcze Żydów, podnosili poziom oświaty ludowej przez propagowanie wartościowych książek i prasy. Namawiali czytelników do korzystania z bibliotek Towarzystwa Czytelni Ludowych i Towarzystwa Szkoły Ludowej. Sprzeciwiali się czytaniu książek i czasopism wydawanych przez Polską Partię Socjalistyczną, które propagowały szkodliwe dla katolika treści. Przestrzegali przed zakupem książek i prasy oferowanych przez zręcznych kolporterów dostarczających je prosto do domów klientów oraz literatury nabywanej podczas jarmarków czy odpustów.
\end{abstract}

Słowa kluczowe: edukacja ludowa, książka, czytelnictwo, czasopisma polskie, XIX-XX wiek

\section{WPROWADZENIE}

Wraz z uprzemysłowieniem, jakie dokonało się w Europie w drugiej połowie XIX stulecia, doszło do rozwoju placówek księgarskich i wydawniczych oraz różnego typu bibliotek, $\mathrm{w}$ tym działających przy licznych stowarzyszeniach o charakterze społecznym i zawodowym. Równocześnie z rozwojem przemysłu 
i unowocześnieniem rolnictwa nastąpił liczebny wzrost robotników oraz podniósł się ich stan uświadomienia klasowego (Ożarzewski 1965, s. 123-125).

Życie społeczeństwa polskiego w drugiej połowie XIX i początkach XX wieku w każdym z zaborów przedstawiało się inaczej. Najgorzej sytuacja wyglądała pod zaborem rosyjskim, gdzie panował wyraźny ucisk polityczny. Były to czasy prześladowań i rusyfikacji narastających po upadku powstania styczniowego. Korzystne warunki dla rozwoju kapitalizmu i uprzemysłowienia ziem polskich pod carskim panowaniem stworzyło uwłaszczenie chłopów w roku 1864. Królestwo Polskie stanowiło też kolebkę klasy robotniczej i tutaj najwcześniej oraz najsilniej rozwinął się ruch socjalistyczny w powiązaniu z organizacjami rewolucyjnymi. Pod zaborem niemieckim, a więc w Wielkim Księstwie Poznańskim, na Pomorzu, Warmii i Mazurach, od 1871 roku ludność polska musiała walczyć z coraz większym uciskiem ekonomicznym i germanizacyjnym. Natomiast pozostająca pod zaborem austriackim Galicja była obszarem najbardziej zacofanym gospodarczo, ale korzystała w wyniku autonomii z licznych swobód politycznych (Ożarzewski 1965, s. 125).

Rozbudzone po 1870 roku życie polityczne pod zaborami sprzyjało rozwojowi zainteresowań problematyką społeczną. Na rynku wydawniczym i prasowym zaczęły pojawiać się książki oraz pisma poruszające tematykę trudnej sytuacji, w jakiej znajdowali się ówcześni włościanie, rzemieślnicy i robotnicy. Wydawano też literaturę i prasę adresowaną do tych grup społecznych. Jednym z periodyków, na łamach którego podejmowano zagadnienia związane z niekorzystną sytuacją społeczną i ekonomiczną klas najmniej uprzywilejowanych, a zwłaszcza robotników, był stanowiący przedmiot niniejszego artykułu „Ruch Chrześcijańsko-Społeczny” wydawany w Poznaniu.

\section{„RUCH CHRZEŚCIJAŃSKO-SPOŁECZNY” (1902-1910) - OGÓLNA CHARAKTERYSTYKA TYTUŁU}

Pierwszy numer pisma „Ruch Chrześcijańsko-Społeczny” wyszedł spod pras drukarskich 1 października 1902 roku, a ostatni 15 września 1910 roku. Jak wskazuje podtytuł, było to pismo o charakterze społecznym i gospodarczym. Stanowiło organ prasowy Katolickiego Towarzystwa Robotników Polskich dla archidiecezji gnieźnieńskiej i poznańskiej. Na szpaltach pisma starano się popularyzować podstawy katolickiej nauki społecznej w nawiązaniu do słynnej encykliki papieża Leona XIII Rerum novarum ogłoszonej 15 maja 1891 roku. Stanowiła ona niezwykle ważny dokument powstawania i rozwoju nauki społecznej Kościoła katolickiego. Papież w swojej encyklice szeroko odniósł się w do kwestii robotniczej, podobnie 
jak czynili to twórcy „Ruchu Chrześcijańsko-Społecznego” (Chamot 1991, s. 59; Szarejko 1998, s. 127).

Omawiany periodyk początkowo ukazywał się co dwa tygodnie - pierwszego i piętnastego dnia każdego miesiąca, a od 1909 roku był miesięcznikiem i wychodził w połowie miesiąca. Tłoczyła go Drukarnia i Księgarnia św. Wojciecha w Poznaniu. Faktycznym wydawcą był zasłużony wielkopolski kapłan, publicysta, pisarz, działacz społeczno-oświatowy i gospodarczy ksiądz Piotr Wawrzyniak (1849-1910), który od roku 1898 kierował tą znaną oficyną. Objętość pojedynczego numeru dwutygodnika wynosiła 28 stron, a miesięcznika - 56 stron. „Ruch Chrześcijańsko-Społeczny" docierał do odbiorców z ziem polskich trzech zaborów. Trudny do ustalenia jest nakład tego pisma, ale na pewno nie przekroczył on 2-5 tysięcy egzemplarzy (Polskie czasopisma... 1988, s. 648; Szarejko 1998, s. 127-130).

„Ruch Chrześcijańsko-Społeczny” powołał do istnienia arcybiskup gnieźnieński i poznański ksiądz Florian Oksza-Stablewski (1841-1906), historyk oraz działacz społeczno-oświatowy. Na stanowisko redaktora wyznaczył protegowanego przez Wawrzyniaka księdza Kazimierza Zimmermanna (18741925), teologa i filozofa, który w latach 1924-1925 był rektorem Uniwersytetu Jagiellońskiego. W okresie 1904-1907 obowiązki redaktora powierzone zostały najaktywniejszemu współpracownikowi Zimmermanna - księdzu Stanisławowi Adamskiemu (1875-1967), od 1930 roku biskupowi diecezji katowickiej (Chamot 1991, s. 8-10; Chamot 1990, s. 177; Łętocha 2010, s. 158; Szarejko 1998, s. 130-135).

Na szpaltach pisma, jak zostało wspomniane, starano się zaakcentować główne kierunki myśli papieża Leona XIII zawarte w encyklice Rerum novarum. Zachęcano do tworzenia katolickich robotniczych zrzeszeń zawodowych, krytykowano szerzący się ruch socjalistyczny, głosząc jego antyreligijność, starano się odsunąć od wpływu na polskie życie gospodarcze Żydów uważanych powszechnie za zdzierców i lichwiarzy. Pisano na temat trudnej sytuacji materialnej i moralnej robotników wyzyskiwanych przez kapitalistów. Domagano się podniesienia poziomu oświaty tej grupy społecznej, co mogło wpłynąć na jej wyższy poziom kulturalny (Krasińska 2017, s. 128-129; Szarejko 1998, s. 138-142).

\section{CZYTELNICTWO WŚRÓD LUDU W ŚWIETLE „RUCHU CHRZEŚCIJAŃSKO-SPOŁECZNEGO”}

Celem niniejszego artykułu jest próba odpowiedzi na pytanie, jak na problem czytelnictwa wśród robotników i włościan z ziem polskich trzech zaborów oraz z zagranicy zapatrywali się twórcy charakteryzowanego pisma i jakie środki podej- 
mowane były w celu popularyzowania wśród klas najmniej uprzywilejowanych oświaty przy pomocy pożytecznej lektury (książki, prasy).

Redakcja „Ruchu Chrześcijańsko-Społecznego” przeciwna była czytaniu książek i czasopism wydawanych przez Polską Partię Socjalistyczną. Starała się zniechęcać odbiorców do ich zakupu, prenumeraty czy korzystania $\mathrm{z}$ nich $\mathrm{w}$ bibliotekach i czytelniach fabrycznych, robotniczych oraz partyjnych. Te ostatnie - zdaniem Jadwigi Krajewskiej (1979) - stanowiły w latach 70. i 80. XIX wieku jedynie składy książek propagandowych. Najbardziej szkodliwe dla katolika były według publicystów omawianego pisma biblioteki Polskiej Partii Socjalistycznej powstające masowo w okresie rewolucji 1905-1907 roku w dużych aglomeracjach miejskich Królestwa Polskiego, np. w Warszawie czy Łodzi. Książnice te zakładano zazwyczaj w wyniku uchwał konferencji partyjnych, podczas których wybierano także bibliotekarzy. Księgozbiory przeznaczano dla działaczy partyjnych, agitatorów oraz bardziej uświadomionych i wykształconych robotników. Utrzymywały się one ze składek członkowskich (Krajewska 1979, s. 111-119).

W bibliotekach partyjnych nie brakowało periodyków socjalistycznych. Za najbardziej szkodliwe publicyści „Ruchu Chrześcijańsko-Społecznego” uważali: „Łodzianina”, „Białostoczanina”, „Górnika”, „Kolejarza”, „Prawo Ludu”, „Radomianina” i „Kurierka Ostrowieckiego” (X.T.G. 1903, s. 330-331).

Nie tylko prasa wydawana przez Polską Partię Socjalistyczną budziła zastrzeżenia twórców omawianego pisma. Ksiądz Arkadiusz Lisiecki (1880-1930), ceniony historyk Kościoła (Jackowski 1972, s. 453-454), przestrzegał przed zakupem książek i prasy oferowanych przez zręcznych kolporterów, którzy dostarczali je prosto do domów klientów, oraz pism nabywanych podczas jarmarków czy odpustów. Była to zdaniem Lisieckiego literatura obliczona na „zaspokojenie najniższych instynktów czytającego ludu", często niemoralna. Duchowny zaliczał do niej powieści kryminalne i sensacyjne pełne opisów brutalnych morderstw, gwałtów, pojedynków, samobójstw, książki przyciągające uwagę kolorową okładką (Lisiecki 1909, s. 357-362).

Przestrzegał też czytelników wychodzącego w Poznaniu w wydawnictwie Franciszka Chocieszyńskiego popularnego tygodnika „Biblioteka Powieści” (18961918), który drukował w odcinkach bezwartościowe, a nawet szkodliwe - według Lisieckiego - literackie „płody”, np.: Czerwony testament Xaviera de Montépina, Na dnie przepaści Georgesa Ohneta, Z tajemnic Wschodu. Obrazki i szkice Walerego Wołodźki czy Sprawę kryminalną. Powiastkę Józefa Ignacego Kraszewskiego. Ksiądz nie polecał również ukazującego się od 1908 roku w Poznaniu tygodnika „Głos Wielkopolanek”, którego dodatek powieściowy zawierał utwory o tak frapujących i krzykliwych tytułach, jak: Wyspa obłąkanych, Przeklęta, Dziesiątka czerwienna i Narzeczona prokuratora. Niepokoił Lisickiego obieg „na siłę do rąk wciskanych” 
książek obliczonych na ciemnotę, łatwowierność i przesądy ludu. Należały do nich wszelkiego typu senniki, kabały oraz przypowieści Sybilli. Odnotował, że zarówno w Poznaniu, jak i na prowincji nie brakowało zainteresowanych tego typu lekturą (Lisiecki 1909, s. 390-393).

Przed nabywaniem oraz czytaniem wątpliwej jakości literatury, jak również zręcznymi jej kolporterami, bazującymi na pobożności i łatwowierności ludu, księża przestrzegali wiernych $\mathrm{z}$ archidiecezji gnieźnieńskiej i poznańskiej podczas niedzielnych i świątecznych kazań. Zachęcali przy okazji do czytania pożytecznych pism oraz książek, które z łatwością można było wypożyczyć w Towarzystwie Czytelni Ludowych, książnicach innych towarzystw o charakterze społecznooświatowym, bibliotekach parafialnych i ludowych (Lisiecki 1909, s. 417-419).

Zachęcano czytelników „Ruchu Chrześcijańsko-Społecznego” do zakupu bądź zaabonowania „Robotnika” (1905-1939). Był to tygodnik adresowany do członków towarzystw robotników katolickich z archidiecezji gnieźnieńskiej i poznańskiej. Ukazywał się, podobnie jak „Ruch Chrześcijańsko-Społeczny”, nakładem Drukarni i Księgarni św. Wojciecha w Poznaniu. Powołał go do istnienia ksiądz Stanisław Adamski, który początkowo był też redaktorem pisma. W 1913 roku nakład „Robotnika” oszacować można było na 31 tysięcy egzemplarzy. W celu pozyskania subskrybentów redakcja udzielała bezpłatnych porad prawnych (Bender 1987, s. 45; Chamot 1990, s. 178; Polskie czasopisma... 1988, s. 609; Ruch ekonomiczno-społeczny... 1906, s. 164).

O potrzebie wydawania tego typu periodyku donoszono czytelnikom „Ruchu Chrześcijańsko-Społecznego" już w 1903 roku. Pisano, że na niedostatecznym wykształceniu robotników oraz braku adresowanego do nich katolickiego pisma korzystają socjaliści nie tylko w silnie uprzemysłowionych miastach Królestwa Polskiego, ale również coraz częściej w mniejszych miejscowościach Wielkiego Księstwa Poznańskiego (Opalenicy, Nakle, Obornikach, Wrześni, Obrzycku). Agitacja socjalistyczna dotarła nawet na wielkopolską wieś. Dlatego sugerowano robotnikom czytanie ukazującego się od 1895 roku „Przewodnika Katolickiego”, którego inicjatorem był arcybiskup Stablewski. Pismo poruszało ważne kwestie społeczne i religijne (W sprawie gazety... 1903, s. 424-432).

Twórcy „Ruchu Chrześcijańsko-Społecznego” zachęcali też do zapoznania się z treścią wydanej około 1901 roku i napisanej w przystępny sposób Książeczki o zdrowiu (260 stron). Opublikowanie tej pożytecznej rozprawy zainicjował Cesarski Urząd Zdrowia w Berlinie. Dzięki niej czytelnik mógł poznać budowę anatomiczną człowieka, dowiedzieć się na temat wpływu atmosfery, wody, klimatu, pożywienia, ruchu na świeżym powietrzu, rozrywki, a nawet odzieży na zdrowie i życie ludzkie. W dziele podano wskazówki dotyczące pielęgnacji w warunkach domowych chorych oraz ofiar nieszczęśliwych wypadków, zaprezentowano też najczęściej występujące choroby zakaźne ( $Z$ „Książeczki o zdrowiu” 1902, s. 23). 
W 1906 roku w piśmie wydrukowany został spis o charakterze bibliograficznym pt. Literatura do kwestii robotniczej (Rzymski 1906a-g). Opracował go posługujący się pseudonimem Dr Teodor Rzymski ksiądz Teodor Kubina (1880-1951), syn górnika, późniejszy biskup częstochowski (Wolny 1971, s. 28). Jak zaznaczył, nie zamierzał zaprezentować tylko literatury „ściśle” katolickiej, adresowanej do robotników, lecz zajął się „prawie wyłącznie zagadnieniami praktycznymi”, przydatnymi tej grupie społecznej w pracy zawodowej oraz życiu. Nie zostawił po sobie samych tylko książek, lecz również obszerniejsze artykuły oraz rozprawy zamieszczane na łamach czasopism poruszających zagadnienia socjalne (Rzymski 1906a, s. 361-362).

„Ruch Chrześcijańsko-Społeczny” poinformował czytelników o powstałej w 1907 roku w Szwajcarii Centrali dla Literatury Społecznej. Jej zadaniem było gromadzenie książek, prasy oraz wszelkich drukowanych dokumentów (statutów, ustaw, sprawozdań różnych towarzystw) odnoszących się do kwestii społecznych i gospodarczych. Do zadań centrali należało też udzielanie ustnych oraz pisemnych porad w sprawach społecznych i literackich (Ruch ekonomiczno-społeczny... 1907, s. 175).

Czytelnicy mieli ponadto sposobność, by dowiedzieć się o funkcjonującym w Berlinie od około 1907 roku Towarzystwie Bibliotekarek. Liczyło ono 82 członkinie, z których przeszło 50 pracowało w bibliotekach naukowych, w tym pięć w książnicy uniwersyteckiej. Do ich obowiązków należało głównie gromadzenie i opracowywanie zbiorów oraz korespondencja z czytelnikami i wydawcami (S.R. 1907, s. 25).

Redakcja omawianego periodyku zachęcała osoby z bardziej oświeconych warstw społecznych, np. duchowieństwa katolickiego i nauczycieli ludowych, by polecały włościanom odpowiednią literaturę, a przez to przyzwyczajały ich do czytania w chwilach wolnych od zajęć. Rekomendowała też zakładanie czytelni dla ludu, gdyż „poziom intelektualny człowieka, który nie czytał książek, niewiele różni się od poziomu dziecka średnio rozwiniętego” (O czytelniach 1903, s. 277). Niepodpisany imieniem i nazwiskiem autor artykułu O czytelniach (1903) dowodził, że często miał do czynienia z sytuacją, gdy popularne wydawnictwa dla ludu, m.in. oficyna Karola Miarki w Mikołowie na Śląsku, wywierały niewielki wpływ na podniesienie poziomu oświaty wśród włościan czy robotników, gdyż wydawane przez nie książki nie przypadły czytelnikom do gustu. Dlatego radził zakładającym czytelnie ludowe, by gromadzili literaturę, którą lud jest w stanie polubić, a co najważniejsze - zrozumieć. Z upływem czasu można było powiększać zbiory takiej czytelni o książki popularnonaukowe, a nawet i naukowe. W czytelniach dla ludu nie powinno zabraknąć bajek i baśni, książek przygodowych, patriotycznych ani wydawnictw o treści religijnej, np. żywotów świętych czy dziełek objaśniających zasady wiary katolickiej. Zorganizowanie dobrej czytelni ludowej nie było sprawą łatwą. Osoba zakładająca taką instytucję oraz zatrudniony w niej bibliotekarz 
musieli przynajmniej pobieżnie znać zawartość treściową znajdujących się na stanie książek i pism. Nie zalecano zakupu książek tanich, bo rzadko zdarzały się wśród nich tytuły wartościowe. Przynajmniej raz w roku polecano przeprowadzać skontrum biblioteczne, a książek zniszczonych nie wypożyczać, lecz oddawać do introligatora. Na barkach założyciela spoczywał też obowiązek organizowania w lokalu czytelni popularyzujących oświatę odczytów. Podczas nich prelegenci mogli mówić na temat obchodzenia się z wypożyczonymi książkami, które niejednokrotnie czytelnicy traktowali jak własność, niszcząc je lub nie zwracając do czytelni. Choć zdaniem autora ówczesny lud był zacofany, to do oświaty się garnął, jeżeli miał ku temu sposobność (O czytelniach 1903, s. 276-281).

Informowano czytelników pisma, że najlepiej rozwijającym się na terenie Cesarstwa Niemieckiego towarzystwem działającym w obszarze oświaty ludowej było istniejące od 1892 roku $^{1}$ Die Deutsche Gesellschaft für Verbreitung von Volksbildung. Do zadań towarzystwa należała promocja edukacji powszechnej; wydawało ono własne godne uwagi czasopismo „Der Bildungsverein”. Przy towarzystwie funkcjonowały stałe i wędrowne biblioteki. Pod koniec 1904 roku organizacja utrzymywała 10672 biblioteki, w których zgromadzonych było zaledwie 354651 tomów książek i pism. Na jedną książnicę przypadały więc około 33 woluminy. Nie lepiej sytuacja przedstawiała się w Wielkim Księstwie Poznańskim, gdzie funkcjonowało 109 stałych i 37 wędrownych bibliotek tego towarzystwa z liczbą 5328 tomów (Gesellschaft für Verbreitung... 2018; Ruch ekonomiczno-społeczny... 1905, s. 305).

Towarzystwa, których zadaniem było szerzenie oświaty wśród ludu, działały również w Anglii, gdzie wprowadzono nawet osobny podatek na rzecz tworzenia bibliotek dla klas najmniej uprzywilejowanych. Angielskie biblioteki ludowe około 1906 roku miały na stanie przeszło 5 milionów tomów książek i pism, a najstarsza tego typu placówka powstała w Manchesterze i w początkach XX wieku udostępniała rocznie blisko 700 tysięcy tomów. Śladami Anglii podążyły jej kolonie, a więc Australia i Nowa Zelandia (X.Z. 1906, s. 291).

We Francji biblioteki ludowe funkcjonowały natomiast w strukturach bibliotek szkolnych jako ich oddziały. Zgromadzone w nich książki miały pobudzać uczucia patriotyzmu wśród czytelników (X.Z. 1906, s. 291).

Jeżeli chodzi o towarzystwa oświaty ludowej w USA i zakładane przy nich biblioteki, to najlepiej sytuacja przedstawiała się w stanie Massachusetts i jego stolicy Bostonie. W początkach 1892 roku biblioteki ludowe w tym okręgu liczyły 2 miliony 750 tysięcy woluminów książek i czasopism (X.Z. 1906, s. 291).

1 Niektóre źródła podają, że Die Deutsche Gesellschaft für Verbreitung von Volksbildung funkcjonowało od 14 czerwca 1871 roku. 
Jedną z najstarszych na ziemiach polskich książnic dla ludu była założona w 1847 roku w Tarnowskich Górach na Górnym Śląsku tzw. biblioteka dla ludu pospolitego. W Bytomiu od września 1848 roku funkcjonowała „czytelnia polska dla ludu". Ta druga była w tym okresie największą na Górnym Śląsku książnicą ludową (Tokarska 1997, s. 60). Musiało jednak brakować tutaj tego typu placówek, skoro w 1896 roku zwróciły na to uwagę władze rejencji opolskiej. Pierwsza biblioteka ludowa w Katowicach powstała - zdaniem korespondenta „Ruchu Chrześcijańsko-Społecznego” Mariana Firleja - dopiero w 1897 roku. W 1903 roku tylko w górnośląskim okręgu przemysłowym funkcjonowało ich 16, wówczas też zaczęły powstawać tam wędrowne biblioteki ludowe. W tym samym roku założony został na Górnym Śląsku Związek Bibliotek Ludowych z siedzibą w Gliwicach, gdzie urzędował sekretarz Karol Kaisig. Poważną funkcję w Związku Bibliotek Ludowych pełnił też tzw. bibliotekarz generalny, do obowiązków którego należała kontrola poszczególnych książnic. W końcu 1904 roku na Górnym Śląsku funkcjonowało już 79 stałych bibliotek ludowych, które udostępniały 584916 tomów książek i pism. Dużą grupę czytelników stanowili górnicy i hutnicy. Z bibliotek tych korzystali również rzemieślnicy, służba domowa, włościanie, kupcy, a nawet urzędnicy, nauczyciele i lekarze. Najczęściej wypożyczano powieści i nowele dla ludu oraz młodzieży, książki historyczne i geograficzne oraz czasopisma. Najmniejszym zainteresowaniem cieszyły się książki religijne. Pod koniec 1905 roku działało też na Górnym Śląsku w strukturach Związku Bibliotek Ludowych około 200 wędrownych książnic (Firlej 1905, s. 553-555).

Z okazji dwudziestopięciolecia utworzonego 11 października 1880 roku w Poznaniu Towarzystwa Czytelni Ludowych twórcy pisma zapoznali czytelników z jego działalnością. Towarzystwo Czytelni Ludowych zastąpiło istniejące od 14 stycznia 1872 roku, a zlikwidowane przez władze niemieckie Towarzystwo Oświaty Ludowej. Celem nowej organizacji było szerzenie pożytecznych i pouczających książek oraz zakładanie bibliotek ludowych. Zasięgiem swego oddziaływania towarzystwo objęło Wielkie Księstwo Poznańskie, Pomorze Gdańskie, Prusy Wschodnie oraz Górny Śląsk; znali je też polscy emigranci przebywającym w Westfalii i Nadrenii. Pierwszym prezesem Towarzystwa Czytelni Ludowych był Mieczysław Łyskowski (1825-1894), działacz społeczno-oświatowy i polityczny. Do grona najaktywniejszych członków towarzystwa można natomiast zaliczyć księdza Antoniego Ludwiczaka (1878-1942), publicystę i ludowego działacza oświatowego (Jakóbczyk 1982, s. 5; Maleczyńska 1987, s. 150-151; Wróblewski 1992, s. 351).

Towarzystwo Czytelni Ludowych wydawało własny organ prasowy, kwartalnik pt. „Czytelnia Ludowa” (1906-1909). Jak podkreślał na łamach „Ruchu Chrześcijańsko-Społecznego” ksiądz Stanisław Adamski, pojawienie się na rynku prasowo-wydawniczym tego tytułu stanowiło doniosły krok w działalności to- 
warzystwa (Adamski 1906, s. 313). Jego zdaniem dobrze rozwijały się zakładane przez towarzystwo biblioteki, a „książki w bezustannym krąż[yły] obiegu”. Aby zorganizować czytelnię, należało posiadać przynajmniej 100 tomów książek i pism. Jak oszacowano, na jedną książnicę przypadało rocznie zaledwie 14 nowych tytułów. Z powodu braku nowości wydawniczo-księgarskich coraz mniej ludzi korzystało z bibliotek. Najaktywniejsi byli dzieci i młodzież. Chcąc zaradzić odpływowi czytelników, w kilku powiatach wprowadzono tzw. wypożyczanie międzybiblioteczne. Towarzystwo Czytelni Ludowych zakładało też biblioteki wędrowne, a na jedną przypadało około 50 książek, które rozsyłano do poszczególnych miejscowości, a latem odsyłano je do centrali. Biblioteki wędrowne działające w strukturach towarzystwa miały swój oddzielny katalog. Adamski poinformował również o funkcjonującej w Wielkim Księstwie Poznańskim „organizacji niemieckich czytelni wędrownych”. Pieczę nad nimi sprawowała Centralna Biblioteka Rządowa w Poznaniu. W początkach 1905 roku działało 384 tego typu placówek, w tym 195 w rejencji poznańskiej i 189 w bydgoskiej (Adamski 1906, s. 314-318).

Ksiądz Adamski zapoznał czytelników „Ruchu Chrześcijańsko-Społecznego” z działającym w zaborze austriackim Towarzystwem Szkoły Ludowej. Powołano je do istnienia 3 maja 1891 roku, czyli w 100. rocznicę uchwalenia Konstytucji 3 maja. Inicjatorem towarzystwa był Adam Asnyk (1838-1897), poeta i dramatopisarz, uczestnik powstania styczniowego (Chrzanowski 1935, s. 171). Za główny cel Towarzystwo Szkoły Ludowej obrało sobie organizację szkolnictwa elementarnego i rozwój czytelnictwa nie tylko w Galicji, ale również na Śląsku Cieszyńskim oraz w Bośni i Hercegowinie. Wśród członków towarzystwa znajdowali się: postępowa inteligencja, studenci i włościanie (Maleczyńska 1987, s. 153). Zdaniem księdza Adamskiego organizacja ta miała bardzo bogaty program działania, chciała „objąć i scentralizować wszystkie środki i drogi służące do pracy kulturalnej” (A.[damski] 1906, s. 434).

Ksiądz Kazimierz Niesiołowski (1872-1949), prezes istniejącego od 1902 roku Związku Księży Abstynentów na archidiecezję gnieźnieńską i poznańską, długoletni proboszcz parafii w Pleszewie (zob. Gulczyński 1995) zwrócił uwagę odbiorcom pisma na czytelnictwo kobiet. Z zadowoleniem odniósł się do działalności funkcjonującego od 15 lutego 1895 roku Towarzystwa Czytelni dla Kobiet w Poznaniu, którego pierwszą przewodniczącą została Wanda Reichsteinowa, zaś bibliotekarkami były Zofia Starkowa i Teresa Pfitznerówna. W dniu otwarcia biblioteka liczyła 150 tomów, a dużym zainteresowaniem czytelników cieszyły się książki historyczne oraz powieści autorów polskich. W lokalu czytelni organizowano odczyty i wykłady (Sprawozdanie Wydziału Czytelni... 1896, s. 3-10). Niesiołowski w swym artykule odnotował, że Czytelnia dla Kobiet w Poznaniu z biegiem czasu powiększała księgozbiór i cieszyła się popularnością wśród czytelniczek. Zachęcał 
do tworzenia czytelni dla kobiet na prowincji, a jako przykład podał znany mu doskonale Pleszew, gdzie tego typu placówkę założono w 1903 roku. W chwili powstania miała ona na stanie około 200 książek, z czego prawie $2 / 3$ stanowiły dary. Jej zarząd organizował interesujące odczyty i pogadanki (Niesiołowski 1903, s. 542-546).

\section{PODSUMOWANIE}

Podsumowując, można stwierdzić, że o rozwoju czytelnictwa wśród robotników i włościan w XIX i początkach XX wieku zadecydowały przemiany społecznopolityczne, jakie dokonały się wówczas na ziemiach polskich. Wymienić tu można np. zniesienie pańszczyzny w Królestwie Polskim, wybuch powstania chłopskiego w roku 1846 w Galicji, uwłaszczenie chłopów oraz rozwój przemysłu i jego modernizacja. Wpływ na czytelnictwo miała również dostępność klas najmniej uprzywilejowanych do oświaty, co w konsekwencji doprowadziło do zmniejszenia analfabetyzmu i wzrostu świadomości obywatelskiej. Na rynku prasowo-wydawniczym zaczęły pojawiać się tytuły adresowane do wspomnianych grup. Dostarczały one wiedzy na temat pracy na roli, w rzemiośle i przemyśle, podawały wskazówki, jak godnie żyć i spędzać czas wolny od zajęć. Jednym z tego typu wydawnictw był zaprezentowany w niniejszym artykule „Ruch Chrześcijańsko-Społeczny”. Należy też wskazać na działalność różnych towarzystw o charakterze oświatowym, społecznym czy zawodowym, chociażby Towarzystwa Szkoły Ludowej i Towarzystwa Oświaty Ludowej. W strukturach tych organizacji funkcjonowały cieszące się dużym zainteresowaniem stałe oraz wędrowne wypożyczalnie i czytelnie. Najczęściej wypożyczano powieści twórców polskich dla ludu, dzieci oraz młodzieży, książki historyczne, geograficzne oraz czasopisma.

\section{LITERATURA}

Adamski S., 1906, Uzupełnienie działalności Towarzystwa Czytelni Ludowych. „Ruch Chrześcijańsko-Społeczny", nr 14, 313-321.

A.[damski] S., 1906, Więcej książnic dla ludu! „Ruch Chrześcijańsko-Społeczny”, nr 19, 433-440.

Bender R., 1987, Katolicka myśl i działalność społeczna w Polsce w XIX i XX wieku (stan badań). Lublin, Redakcja Wydawnictw KUL.

Chamot M., 1991, Polska myśl chrześcijańsko-społeczna w zaborze pruskim w latach 1890-1918. Toruń, Wydawnictwo Adam Marszałek. 
Chamot M., 1990, Rola społeczna duchowieństwa w polskiej myśli chrześcijańskospołecznej Poznańskiego (1890-1914). W: S. Kalemba (red.), Studia z dziejów polskiej myśli politycznej, t. 2. Polska myśl polityczna $w$ dzielnicy pruskiej w XIX w. Zbiór studiów. Toruń, Wydawnictwo UMK, 171-187.

Chrzanowski I., 1935, Asnyk Adam Prot. W: Polski Słownik Biograficzny, t. 1. Kraków, nakładem Polskiej Akademii Umiejętności, 171-173.

Firlej M., 1905, Niemieckie biblioteki ludowe na Górnym Śląsku. „Ruch ChrześcijańskoSpołeczny", nr 24, 553-558.

Gesellschaft für Verbreitung von Volksbildung, 2018, opublikowano: https://de.wikipedia. org/wiki/Gesellschaft_f\%C3\%BCr_Verbreitung_von_Volksbildung [dostęp: 27.10.2017].

Gulczyński A., 1995, Ks. prałat Kazimierz Niesiołowski 1872-1949. Pleszew, Pleszewskie Towarzystwo Kulturalne.

Jackowski J., 1972, Lisiecki Arkadiusz Marian. W: Polski Słownik Biograficzny, t. 17. Wrocław, Zakład Narodowy im. Ossolińskich; Wydawnictwo Polskiej Akademii Nauk, 453-454.

Jakóbczyk W., 1982, Towarzystwo Czytelni Ludowych 1880-1939: w obronie narodowości. Poznań, Krajowa Agencja Wydawnicza.

Krajewska J., 1979, Czytelnictwo wśród robotników w Królestwie Polskim 1870-1914. Warszawa, Państwowe Wydawnictwo Naukowe.

Krasińska I., 2017, Sytuacja żeńskiej służby domowej w świetle poznańskiego czasopisma „Ruch Chrześcijańsko-Społeczny” (1902-1910). „Studia Gdańskie”, t. 40, 123-135.

Lisiecki A., 1909, Kolportaż pożytecznych pism i książek. „Ruch ChrześcijańskoSpołeczny", nr 13, 357-362.

Lisiecki A., 1909, Kolportaż pożytecznych pism i książek (ciag dalszy). „Ruch Chrześcijańsko-Społeczny”, nr 14, 390-394.

Lisiecki A., 1909, Kolportaż pożytecznych pism i książek (dokończenie). „Ruch Chrześcijańsko-Społeczny”, nr 15, 417-422.

Lesisz B. i in. (red.), 1988, Polskie czasopisma religijno-społeczne w XIX wieku. Materiały do katalogu. Warszawa-Lublin, Redakcja Wydawnictw KUL.

Łętocha R., 2010, Myśl i działalność społeczna biskupa Stanisława Adamskiego. W: E. Przybył-Sadowska, D. Szymańska-Kuty (red.), Orbis Christianus. Studia ofiarowane Profesorowi Janowi Drabinie. Kraków, Wydawnictwo Uniwersytetu Jagiellońskiego, 157-167.

Maleczyńska K., 1987, Książki i biblioteki w Polsce okresu zaborów. Wrocław, Zakład Narodowy im. Ossolińskich.

Niesiołowski [K.], 1903, O czytelniach dla kobiet. „Ruch Chrześcijańsko-Społeczny”, nr 23, 542-546.

O czytelniach, 1903, „Ruch Chrześcijańsko-Społeczny”, nr 12, 276-281. 
Ożarzewski C., 1965, Zarys dziejów książki i księgarstwa. Poznań, Wydawnictwo Poznańskie.

Potoczny J., 2014, Udział Towarzystwa Szkoły Ludowej w upowszechnianiu czytelnictwa i popularyzacji wiedzy wśród ludu galicyjskiego doby autonomicznej. „Prace Naukowe Akademii im. Jana Długosza w Częstochowie. Pedagogika”, t. 23, 401-414. Ruch ekonomiczno-społeczny. Centrala dla literatury społecznej, 1907. „Ruch Chrześcijańsko-Społeczny”, nr 7, 175.

Ruch ekonomiczno-społeczny. Niemieckie czytelnie ludowe, 1905. „Ruch ChrześcijańskoSpołeczny", nr 13, 305-306.

Ruch ekonomiczno-społeczny. Nowe pismo dla robotników, 1906. „Ruch ChrześcijańskoSpołeczny", nr 7, 164.

Rzymski T., 1906a, Literatura do kwestii robotniczej. „Ruch Chrześcijańsko-Społeczny”, nr 16, 361-366.

Rzymski T., 1906b, Literatura do kwestii robotniczej (ciagg dalszy). „Ruch ChrześcijańskoSpołeczny", nr 17, 390-394.

Rzymski T., 1906c, Literatura do kwestii robotniczej (ciagg dalszy). „Ruch ChrześcijańskoSpołeczny", nr 18, 413-419.

Rzymski T., 1906d, Literatura do kwestii robotniczej (ciagg dalszy). „Ruch ChrześcijańskoSpołeczny", nr 19, 443-446.

Rzymski T., 1906e, Literatura do kwestii robotniczej (ciagg dalszy). „Ruch ChrześcijańskoSpołeczny", nr 20, 465-468.

Rzymski T., 1906f, Literatura do kwestii robotniczej (ciąg dalszy). „Ruch ChrześcijańskoSpołeczny", nr 21, 488-491.

Rzymski T., 1906g, Literatura do kwestii robotniczej (ciagg dalszy). „Ruch ChrześcijańskoSpołeczny", nr 22, 514-517.

Sprawozdanie Wydziału Czytelni dla Kobiet w Poznaniu z czynności w roku pierwszym istnienia tejże 1895/96, 1896. Poznań, Nakładem Czytelni dla Kobiet.

[S.R.], 1907, Towarzystwo Bibliotekarek. „Ruch Chrześcijańsko-Społeczny”, nr 1, 25. Szarejko H., 1998, Dwutygodnik „Ruch Chrześcijańsko-Społeczny” (Poznań 1902-1910), cz. 1. „Rocznik Naukowo Dydaktyczny WSP w Krakowie. Prace Bibliotekoznawcze", z. 194, 127-142.

Tokarska A., 1997, Biblioteki polskie na Górnym Śląsku w XIX wieku. Katowice, Wydawnictwo Uniwersytetu Śląskiego.

W sprawie gazety dla robotników, 1903. „Ruch Chrześcijańsko-Społeczny”, nr 18, 424-432. Wolny J., 1971, Kubina Teodor Filip. W: Polski Słownik Biograficzny, t. 16. WrocławWarszawa-Kraków, Zakład Narodowy im. Ossolińskich; Wydawnictwo Polskiej Akademii Nauk.

Wróblewski J., 1992, Ocalałe książki z bibliotek Towarzystwa Czytelni Ludowych na Warmii i Mazurach. „Komunikaty Mazursko-Warmińskie”, nr 3-4, 351-360. 
X.T.G., 1903, Kilka uwag o socjalnych czasopismach dla ludu. Z powodu „Ostatnich doświadczeń” X. arcybiskupa Teodorowicza. „Ruch Chrześcijańsko-Społeczny”, nr 14, 330-333.

X.Z., 1906, Z okazji ćwierćwiekowej działalności Towarzystwa Czytelni Ludowych. „Ruch Chrześcijańsko-Społeczny”, nr 13, 289-295.

Z „Książeczki o zdrowiu”, 1902. „Ruch Chrześcijańsko-Społeczny”, nr 1, 23-24.

\title{
POPULARIZATION OF READING GIVEN IN THE POZNAŃ PERIODICAL “CHRISTIAN- -SOCIAL MOVEMENT" (1902-1910)
}

\begin{abstract}
As a result of the industrialization in the 19th century there was an increase in the number of working class representatives, and the abolition of serfdom resulted in the improvement of peasantry position. Books and newspapers also began to be popular among those social groups. One of such periodicals was "Christian-Social Movement" (1902-1910). The authors of the periodical encouraged readers to create the Catholic workers' unions, and criticized the growing socialist movement emphasizing its anti-religiousness. The periodical strove against Jewish influence on Polish economic life. Moreover, they promoted valuable books and press. Readers were encouraged to use the library of the People's Reading Society or the Society of the People's School. They opposed reading books and periodicals published by the Polish Socialist Party, which propagated contents which were harmful to the Catholics. They warned not to buy books and magazines during fairs or the ones offered by skillful salesmen who delivered them directly to the clients' homes.
\end{abstract}

Keywords: folk education, book, reading, Polish magazines, XIX-XX century 